\title{
ANALISIS KEMAMPUAN BERPIKIR KRITIS MATEMATIS MAHASISWA DALAM MENYELESAIKAN SOAL URAIAN KALKULUS INTEGRAL BERDASARKAN LEVEL KEMAMPUAN MAHASISWA
}

\author{
Oleh: \\ ${ }^{1)}$ Zetriuslita, ${ }^{2)}$ Rezi Ariawan, ${ }^{3)}$ Hayatun Nufus \\ 1,2 Pendidikan Matematika Universitas Islam Riau, \\ ${ }^{3}$ Pendidikan Matematika UIN Sultan Syarif Qasim Riau \\ ${ }^{1}$ zetri.lita@gmail.com, ${ }^{2}$ ariawanrezi@ rocketmail.com, ${ }^{3}$ ya2tun@yahoo.com
}

\begin{abstract}
ABSTRAK
Penelitian ini bertujuan untuk menggambarkan kemampuan mahasiswa dalam menyelesaikan setiap soal uraian kalkulus integral yang disusun berdasarkan indikator kemampuan berpikir kritis matematis dan berdasarkan level akademik mahasiswa. Bentuk penelitian yang digunakan adalah penelitian kualitatif. Subyek dalam penelitian ini adalah mahasiswa semester 2 tahun ajaran 2014/2015 Program Studi Pendidikan Matematika FKIP UIR Pekanbaru yang sedang mengikuti mata kuliah kalkulus 2 berjumlah sebanyak 115 orang. Subjek dibagi atas tiga kelompok yaitu mahasiswa pada level kemampuan tinggi (10 orang), mahasiswa pada level kemampuan sedang (88 orang), dan mahasiswa pada level kemampuan rendah (17 orang). Teknik pengumpulan data dalam penelitian ini menggunakan teknik tes dan wawancara. Pengolahan keabsahan data menggunakan teknik triangulasi (mereduksi data, penyajian data, dan penarikan kesimpulan). Berdasarkan hasil penelitian diketahui bahwa: (1) Mahasiswa pada level kemampuan tinggi yang menjawab dengan benar soal pada indikator 1 sebanyak 4 orang (40\%), indikator 2 sebanyak 8 orang $(80 \%)$, dan indikator 3 sebanyak 5 orang (50\%); (2) Mahasiswa pada level kemampuan sedang yang menjawab dengan benar soal pada indikator 1 sebanyak 5 orang $(5,68 \%)$, indikator 2 sebanyak 75 orang $(85,23 \%)$, dan indikator 3 sebanyak 8 orang $(9,09 \%)$; (3) Mahasiswa pada level kemampuan rendah yang menjawab dengan benar soal pada indikator 1 sebanyak 0 orang $(0 \%)$, indikator 2 sebanyak 13 orang $(68,42 \%)$, indikator 3 sebanyak 5 orang (26,32\%); (4) Secara keseluruhan, indikator 1 sebanyak 9 orang $(7,69 \%)$, indikator 2 sebanyak 96 orang $(82,05 \%)$, dan indikator 3 sebanyak 18 orang $(15,38 \%)$.
\end{abstract}

Kata Kunci : Kemampuan Berpikir Kritis Matematis, Level Kemampuan Mahasiswa

\begin{abstract}
This research aims to describe the ability of students to solve any problem at integral calculus course which is based indicators of mathematical critical thinking ability and level mathematical ability of students. Research method used in this study is a qualitative research. Subjects in this study were students of the 2nd semester 2014/2015 academic year at Mathematics Education FKIP UIR Pekanbaru. This population of this study were 115 students participating in integral calculus course. Subjects were divided into three groups: students in high-level abilities (10), students in medium-level (88), and students in low-level (17). Data collection techniques in this study using the test and interview techniques. Processing of data validity using triangulation techniques (data reduction, data presentation, and conclusion). Based on the results of the study are found that: (1) Students at a highlevel correctly answering questions on the indicator 1 of 4 students (40\%), indicator 2 of 8 students $(80 \%)$, and 3 indicators as much (50\%); (2) Students at the level of ability is being correctly answering questions on the indicator 15 students $(5.68 \%)$, indicator 2 many as 75 students $(85.23 \%)$, and indicators 3 of 8 persons $(9.09 \%)$; (3) Students at a low level ability correctly answering questions on a first indicator from $0(0 \%)$, indicator 2 as many as 13 students $(68.42 \%)$, indicator 3 by 5 votes
\end{abstract}


(26.32\%); (4) Overall, the indicators one by 9 votes (7.69\%), indicator 2 as many as 96 students $(82.05 \%)$, and a third indicator as many as 18 students $(15.38 \%)$.

Keywords: mathematical critical thinking ability, level mathematical ability of students

\section{PENDAHULUAN}

Dalam setiap kurikulum pendidikan nasional Indonesia, mata pelajaran matematika selalu diajarkan disetiap jenjang pendidikan, tidak terkecuali di perguruan tinggi. Hal ini menunjukkan bahwa diharapkan dengan mempelajari matematika, maka ketersediaan akan sumber daya manusia Indonesia yang handal, yakni mampu berpikir kritis, sistematis, logis, kreatif, dan cermat dapat terpenuhi.

Salah satu aspek penting dalam matematika di perguruan tinggi adalah kemampuan berpikir kritis. Hal ini sejalan dengan apa yang direkomendasikan oleh Committee on the Undergroude Program in Mathematics dalam Karlimah (2010) yaitu " enam rekomendasi dasar untuk jurusan, program, dan mata kuliah dalam matematika. Salah satu rekomendasinya menjelaskan bahwa setiap mata kuliah dalam matematika hendaknya merupakan aktivitas yang akan membantu mahasiswa dalam pengembangan analitis, penalaran kritis, pemecahan masalah, dan keterampilan komunikasi.

Klurik dan Rudnick (Sabandar, 2008) menyatakan bahwa yang termasuk berpikir kritis dalam matematika adalah berpikir yang menguji, mempertanyakan, menghubungkan, mengevaluasi semua aspek yang ada dalam suatu situasi maupun dalam suatu masalah. Hassoubah, 2004), berpikir kritis adalah berpikir secara beralasan dan reflektif dengan menekankan pada pembuatan keputusan tentang apa yang harus dipercayai atau dilakukan.

Mason (2010) dalam Lunenburg (2011) menyatakan bahwa konsep berpikir kritis salah satu trend yang paling signifikan dalam pendidikan dan memiliki hubungan yang dinamis bagaimana guru mengajar dan peserta didik belajar. Lunenburg menambahkan setelah kita memahami konten yang tidak terpisahkan dari pemikiran yang menghasilkan, mengatur, menganalisis, mensin-tesis, mengevaluasi, dan mentransformasinya. Sejalan dengan itu Marzano (1989) berpikir kritis adalah sesuatu yang masuk akal, berpikir reflektif yang difokuskan pada apa keputusan yang diyakini, dikerjakan dan diperbuat.

Selanjutnya Facione (2011) bahwa konsep dasar dari berpikir kritis adalah interpretasi, analisis, evaluasi, menyimpulkan, penjelasan dan kepercayaan diri. Sedangkan berpikir kritis menurut Onosko and Newmann (1994) bagaimana menantang peserta didik dalam menginterpretasikan, menganalisis dan memanipulasi informasi. Oleh karena itu keterampilan berpikir kritis diperlukan ketika kita mencoba memahami informasi yang akan digunakan untuk mencetuskan ide atau gagasan. (Firdaus et.al (2015).

Berpikir kritis menurut Johnson (2007) merupakan sebuah proses terarah dan jelas yang digunakan dalam kegiatan mental seperti memecahkan masalah, mengambil keputusan, membujuk, menganalisis asumsi, dan melakukan penelitian ilmiah. Senada dengan itu, Ennis yang dikutip Lipman (2003) mengemukakan aspek dalam berpikir kritis adalah focus (fokus), reasons (alasan), inference (simpulan), situation (situasi), clarity (kejelasan), dan overview (tinjau ulang). 
Berdasarkan pernyataan di atas, dapat disimpulkan bahwa kemampuan berpikir kritis dapat membuat dan melatih seseorang untuk melakukan (doing math) dalam pembelajaran matematika. Kemampuan berpikir kritis matematis adalah kemampuan matematika tingkat tinggi yang dalam penelitian ini diukur dengan menggunakan indikator: (1) Kemampuan mengidentifikasi dan menjastifikasi konsep, yaitu kemampuan memberikan alasan terhadap penguasan konsep; (2) Kemampuan menggeneralisasi, yaitu kemampuan melengkapi data atau informasi yang mendukung; (3) Kemampuan menganalisis algoritma, yaitu kemampuan mengevaluasi atau memeriksa suatu algoritma.

Berdasarkan latar belakang di atas, maka rumusan masalah dalam penelitian ini adalah: Bagaimanakah kemampuan berpikir kritis mahasiswa dalam menyelesaikan soal uraian kalkulus integral ditinjau berdasarkan indikator kemampuan berpikir kritis matematis dan level kemampuan mahasiswa?

Adapun tujuan dalam penelitian ini mendiskripsikan dan menganalisis kemampuan berpikir kritis mahasiswa dalam menyelesaikan soal uraian kalkulus integral ditinjau berdasarkan indikator kemampuan berpikir kritis matematis dan level kemampuan mahasiswa.

\section{METODE PENELITIAN}

Metode penelitian yang digunakan dalam penelitian ini adalah kualitatif. Subjek dalam penelitian ini adalah mahasiswa semester 2 Program Sudi Pendidikan Matematika FKIP UIR semester genap yang sedang menempuh mata kuliah kalkulus 2. Pemilihan subjek penelitian ini didasari oleh beberapa pertimbangan, yaitu: (a) mahasiswa semester 2 sudah mendapatkan mata kuliah kalkulus 1, sehingga dapat dikatakan mereka sudah memenuhi syarat untuk mempelajari kalkulus 2; (b) mudah diwawancarai sehingga akan diperoleh data akurat yang dibutuhkan dalam penelitian ini.

\section{HASIL PENELITIAN DAN PEMBAHASAN}

Pengambilan data pada penelitian ini dilakukan di Ruangan A6.09 - A6.14 Kampus FKIP UIR Pekanbaru pada tanggal 11-13 Mei 2015 pada jam 09.00-12.00 WIB. Setelah subjek penelitian mengerjakan lembar instrumen berpikir kritis matematis, selanjutnya peneliti menentukan subjek yang akan diwawancara berdasarkan tingkat kemampuan akademik. Setelah proses wawancara selesai, maka peneliti melakukan analisis data penelitian.

Analisis data penelitian dilakukan dengan memaparkan jawaban subjek penelitian secara tertulis dan kemudian dilanjutkan dengan memaparkan hasil wawancara peneliti dengan subjek. Terakhir peneliti akan melakukan hasil triangulasi dari data yang telah diperoleh.

Tabel berikut adalah paparan kemampuan berpikir kritis mahasiswa dalam menyelesaikan soal uraian kalkulus integral ditinjau dari tiap indikator dan level kemampuan matematis mahasiswa. 
Tabel 1.

Kemampuan Berpikir Kritis Matematis Mahasiswa Berdasarkan Indikator Kemampuan Berpikir Kritis Matematis dan Level Kemampuan

\begin{tabular}{ccccccccccccc}
\hline \multirow{2}{*}{$\begin{array}{c}\text { Level } \\
\text { Kemampuan }\end{array}$} & \multicolumn{10}{c}{$\mathbf{1}$ Indikator Kemampuan Berpikir Kritis Matematis } \\
\cline { 2 - 14 } & $\mathbf{B}$ & $\mathbf{\%}$ & $\mathbf{S}$ & $\mathbf{\%}$ & $\mathbf{B}$ & $\mathbf{\%}$ & $\mathbf{S}$ & $\mathbf{\%}$ & $\mathbf{B}$ & $\mathbf{\%}$ & $\mathbf{3}$ & $\mathbf{\%}$ \\
\hline Tinggi & 4 & $40 \%$ & 6 & $60 \%$ & 8 & $80 \%$ & 2 & $20 \%$ & 5 & $50 \%$ & 5 & $50 \%$ \\
Sedang & 5 & $5,68 \%$ & 83 & $94,31 \%$ & 75 & $85,23 \%$ & 13 & $14,77 \%$ & 8 & $9,09 \%$ & 80 & $90,91 \%$ \\
Rendah & 0 & $0 \%$ & 19 & $100 \%$ & 13 & $68,42 \%$ & 6 & $31,58 \%$ & 5 & $26,32 \%$ & 14 & $73,68 \%$ \\
Jumlah & 9 & $7,69 \%$ & 108 & $92,30 \%$ & 96 & $82,05 \%$ & 19 & $16,24 \%$ & 18 & $15,38 \%$ & 97 & $82,90 \%$ \\
\hline
\end{tabular}

\section{Keterangan:}

Indikator 1: Kemampuan mengidentifikasi dan menjastifikasi konsep, yaitu kemampuan memberikan alasan terhadap penguasaan konsep.

Indikator 2: Kemampuan mengeneralisasi, yaitu kemampuan melengkapi data atau informasi yang mendukung.

Indikator 3: Kemampuan menganalisis algoritma, yaitu mengevaluasi atau memeriksa suatu algoritma.

B: $\quad$ Menjawab Benar

S: $\quad$ Menjawab Salah

Berdasarkan tabel di atas terlihat bahwa secara keseluruhan jumlah mahasiswa yang menjawab dengan benar paling banyak adalah untuk indikator 2 yaitu sebanyak 96 orang atau $82,05 \%$. Sedangkan jumlah mahasiswa yang menjawab dengan benar paling sedikit adalah untuk indikator 1 yaitu sebanyak 9 orang atau 7,69\%. Hal ini mengindikasikan bahwa mahasiswa sudah mampu untuk melakukan generalisasi yang ditandai dengan mampu untuk melengkapi data atau informasi yang mendukung. Selanjutnya sebagian besar mahasiswa dapat dikatakan belum memiliki kemampuan untuk mengidentifikasi dan menjastifikasi konsep yang diperlukan untuk menyelesaikan masalah dan juga belum memiliki kemampuan menganalisis yang ditandai belum mampu mengevaluasi kebenaran dari sebuah jawaban yang disajikan.

Dari lembar jawaban mahasiswa, peneliti mendapatkan informasi bahwa sebagian besar mahasiswa tidak dapat menyelesaikan soal untuk indikator 1 dengan benar, disebabkan oleh: (1) mahasiswa tidak dapat membuat sketsa kurva dari persamaan yang diberikan; (2) mahasiswa tidak dapat menentukan batas-batas yang merupakan perpotongan dari persamaan yang diberikan; (3) mahasiswa tidak dapat menentukan konsep luas mana yang akan digunakan, apakah luas di atas sumbu-x, luas di bawah sumbu- $\mathrm{x}$ atau luas diantara dua kurva. Sedangkan untuk indikator 3, mahasiswa tidak dapat menyelesaikan soal dengan benar disebabkan oleh: (1) mahasiswa masih belum memahami tentang konsep integral trigonometri sehingga tidak dapat menentukan apakah jawaban yang disajikan sudah benar atau belum; (2) ada sebagaian yang sudah bisa menentukan jawaban yang disajikan salah, tetapi tidak bisa menyatakan mana bagian yang salah dan tidak dapat menyatakan jawaban yang benarnya. Selanjutnya berdasarkan lembar jawaban mahasiswa untuk indikator 2, peneliti menemukan bahwa hampir semua mahasiswa bisa melengkapi data yang diberikan, hal ini mengindikasikan bahwa mahasiswa sudah memahami konsep integral rasional bentuk faktor linier. 
Untuk lebih memberikan informasi tentang pernyataan diatas dapat dilihat dari triangulasi hasil jawaban, wawancara yang diperoleh dari mahasiswa level kemampuan tinggi, sedang dan rendah.

\section{a. Analisis Data Mahasiswa Level Kemampuan Tinggi}

Setelah diperoleh hasil analisis jawaban tertulis dan analisis data wawancara, selanjutnya dilakukan perbandingan untuk mengetahui valid tidaknya data yang diperoleh. Berikut adalah rangkuman kemampuan berpikir kritis matematis mahasiswa level kemampuan rendah berdasarkan data tertulis dan data wawancara dan hasil triangulasi.

Tabel 2.

Triangulasi dari Hasil Jawaban dan Wawancara Mahasiswa dari Level Kemampuan Tinggi Indikator

Kemampuan

Berpikir Kritis

Hasil Tes Tertulis

Hasil Wawancara

Matematis

1. Kemampuan

mengidentifikasi

dan menjastifikasi

konsep, yaitu

kemampuan

memberikan alasan

terhadap

penguasaan konsep

- Jelas dalam menuliskan jawaban

- Memberikan respon terhadap soal tes yang diberikan

- Tidak menentukan titik puncak dari persamaan parabola diberikan

yang

Tidak menentukan titik potong persamaan garis yang diberikan dengan persamaan parabola

- Mencoba membuat sketsa gambar dari persamaan parabola dan garis yang diberikan, tetapi masih salah.

- Salah dalam menentukan batas integral tentu, yang berakibat salah dalam menentukan luas daerah yang diarsir.

2. Kemampuan menggeneralisasi, yaitu kemampuan melengkapi data atau informasi yang mendukung
- Jelas menuliskan jawaban

- Melengkapi data yang diberikan, walaupun dibagian akhir selesaian terdapat sedikit kesalahan.
- Dapat menyebutkan apa saja yang ditanyakan dari soal

- Informasi yang diberikan tidak cukup untuk menyelesaikan soal

- Kesulitan dalam menggambar kurva dari persamaan yang diberikan yang diakibatkan tidak mengetahui titik potong dari persamaan parabola yang diberikan dengan garis.

- Alasan yang diberikan dalam menentukan luas daerah yang dibatasi oleh parabola dan garis masih salah karena karena tidak bisa menentukan batas integral yang digunakan.
- Dapat menyebutkan apaapa saja yang harus dilakukan dalam menyelesaikan persoalan

- Dapat menyelesaikan persoalan dengan melengkapi data yang diberikan, namun belum benar karena ada beberapa hal yang lupa dan kurang teliti 


\begin{tabular}{|c|c|c|}
\hline $\begin{array}{c}\text { Indikator } \\
\text { Kemampuan } \\
\text { Berpikir Kritis } \\
\text { Matematis }\end{array}$ & Hasil Tes Tertulis & Hasil Wawancara \\
\hline $\begin{array}{l}\text { 3. Kemampuan } \\
\text { menganalisis } \\
\text { algoritma, yaitu } \\
\text { kemampuan } \\
\text { mengevaluasi atau } \\
\text { memeriksa suatu } \\
\text { algoritma }\end{array}$ & $\begin{array}{l}\text { - Jelas dalam } \\
\text { memberikan jawaban } \\
\text { - Tidak memberikan } \\
\text { evaluasi terhadap } \\
\text { sebuah pernyataan } \\
\text { yang diajukan. } \\
\text { - Memberikan koreksian } \\
\text { terhadap pernyataan } \\
\text { yang diberikan, namun } \\
\text { masih salah. }\end{array}$ & $\begin{array}{l}\text { - } \text { Tidak memberikan } \\
\text { evaluasi terhadap sebuah } \\
\text { pernyataan yang diajukan. } \\
\text { - Mengetahui bahwa } \\
\text { persoalan merupakan } \\
\text { integral tirgonometri, } \\
\text { tetapi tidak dapat } \\
\text { memberikan koreksian } \\
\text { dimana letak kesalahan, } \\
\text { sehinggaperbaikan } \\
\text { diberikan masih salah. }\end{array}$ \\
\hline
\end{tabular}

\section{Kesimpulan}

1. Mahasiswa tidak dapat mengidentikasi konsep yang dibutuhkan untuk menyelesaikan persoalan, namun mahasiswa tidak dapat melakukan jastfikasi dan memberikan alasan dalam menyelesaikan persoalan yang diberikan.

2. Mahasiswa dapat melakukan generalisasi dengan melengkapi data atau informasi yang mendukung, walaupun melakukan sedikit kesalahan yan disebabkan oleh faktor kurang teliti

3. Mahasiswa tidak dapat menganalisis dan melakukan evaluasi dari persoalan yang diberikan, tetapi mahasiswa dapat menentukan jenis persoalan yang diberikan

\section{b. Analisis Data Mahasiswa Level Kemampuan Sedang}

Setelah diperoleh hasil analisis jawaban tertulis dan analisis data wawancara, selanjutnya dilakukan perbandingan untuk mengetahui valid tidaknya data yang diperoleh. Berikut adalah rangkuman kemampuan berpikir kritis matematis mahasiswa level kemampuan rendah berdasarkan data tertulis dan data wawancara dan hasil triangulasi.

Tabel 3

Triangulasi dari Hasil Jawaban dan Wawancara Mahasiswa dari Level Kemampuan Sedang Indikator

Kemampuan Berpikir Kritis

Hasil Tes Tertulis

Hasil Wawancara Matematis

\begin{tabular}{llll}
\hline 1. Kemampuan & Tidak memberikan & - Dapat menyebutkan apa \\
mengidentifikasi & jawaban & & saja yang diketahui dan \\
dan menjastifikasi & & yang ditanyakan, tetapi \\
konsep, yaitu & & tidak bisa menyelesaikan \\
kemampuan & & persoalan yang ada, \\
memberikan alasan & & karena tidak mengetahui \\
terhadap & & konsep selesaiannya. \\
penguasaan konsep & & \\
\hline
\end{tabular}




\begin{tabular}{|c|c|c|}
\hline $\begin{array}{c}\text { Indikator } \\
\text { Kemampuan } \\
\text { Berpikir Kritis } \\
\text { Matematis }\end{array}$ & Hasil Tes Tertulis & Hasil Wawancara \\
\hline $\begin{array}{l}\text { 2. Kemampuan } \\
\text { menggeneralisasi, } \\
\text { yaitu kemampuan } \\
\text { melengkapi data } \\
\text { atau informasi } \\
\text { yang mendukung }\end{array}$ & 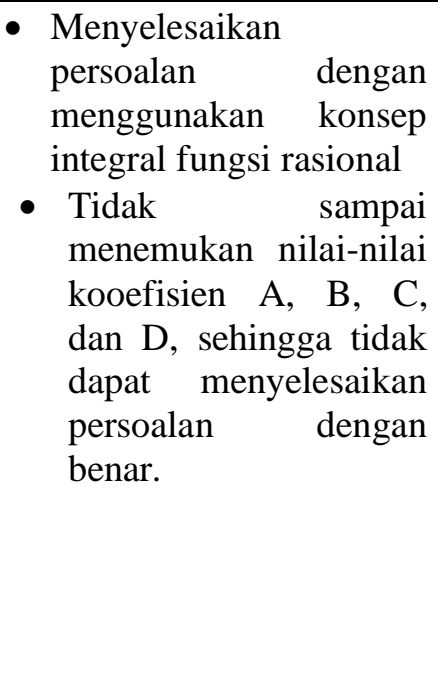 & 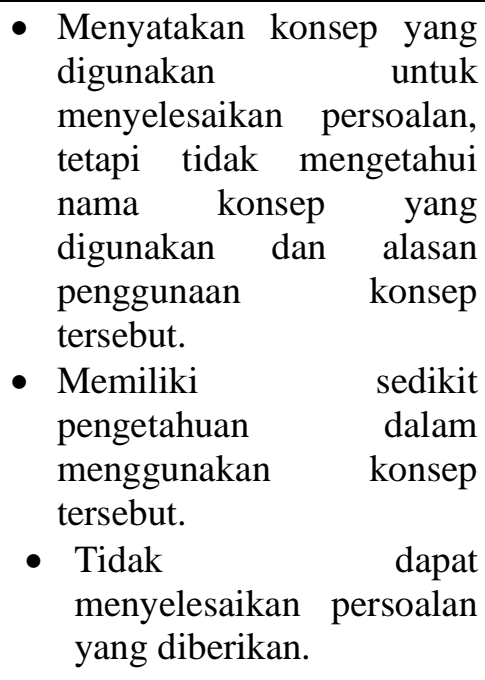 \\
\hline $\begin{array}{l}\text { 3. Kemampuan } \\
\text { menganalisis } \\
\text { algoritma, yaitu } \\
\text { kemampuan } \\
\text { mengevaluasi atau } \\
\text { memeriksa suatu } \\
\text { algoritma }\end{array}$ & 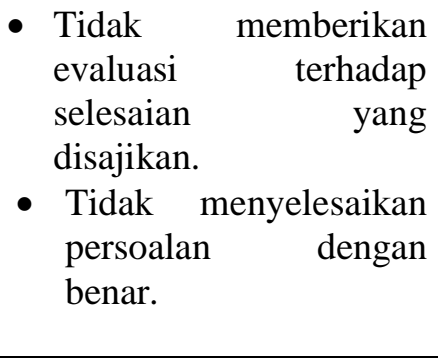 & $\begin{array}{l}\text { - } \text { Memberikan evaluasi } \\
\text { terhadap selesaian yang } \\
\text { diberikan, namun masih } \\
\text { salah. } \\
\text { - Tidak memahami } \\
\text { bagaimana } \\
\text { menyelesaiakan persoalan } \\
\text { yang ada. }\end{array}$ \\
\hline
\end{tabular}

\section{Kesimpulan :}

1. Mahasiswa tidak dapat mengidentifikasi dan menjastifikasi pengetahuan yang dibutuhkan untuk menyelesaikan soal, serta belum mampu memberikan alasan dengan benar terhadap selesaian yang diberikan.

2. Mahasiswa tidak dapat melakukan generalisasi dengan melengkapi data atau informasi yang mendukung dengan benar.

3. Mahasiswa tidak dapat mengevaluasi dengan benar persoalan yang diberikan, tetapi tidak mampu menganalasis persoalan yang diberikan, serta tidak mampu menyelesaiakan persoalan dengan benar.

\section{c. Analisis Data Mahasiswa Level Kemampuan Rendah}

Setelah diperoleh hasil analisis jawaban tertulis dan analisis data wawancara, selanjutnya dilakukan perbandingan untuk mengetahui valid tidaknya data yang diperoleh. Berikut adalah rangkuman kemampuan berpikir kritis matematis mahasiswa level kemampuan rendah berdasarkan data tertulis dan data wawancara dan hasil triangulasi.

Tabel 4

Triangulasi dari Hasil Jawaban dan Wawancara Mahasiswa dari Level Kemampuan Rendah Indikator Kemampuan Berpikir Kritis Hasil Tes Tertulis Hasil Wawancara Matematis

\begin{tabular}{|c|c|c|}
\hline 1. Kemampuan & - Tidak menentukan titik & menyebutkan \\
\hline mengidentifikasi & potong antara parabola, garis & yang \\
\hline menjastifikasi konsep, & dan sumbu y. & ditanyakan, dan \\
\hline kemampuan & membuat & mengetahui \\
\hline
\end{tabular}




\begin{tabular}{|c|c|c|}
\hline $\begin{array}{c}\text { Indikator Kemampuan } \\
\text { Berpikir Kritis } \\
\text { Matematis } \\
\end{array}$ & Hasil Tes Tertulis & Hasil Wawancara \\
\hline $\begin{array}{l}\text { memberikan alasan } \\
\text { terhadap penguasaan } \\
\text { konsep }\end{array}$ & $\begin{array}{l}\text { persamaan garis, namun } \\
\text { tidak membuat } \\
\text { parabots sehingga tidak } \\
\text { dapat menentukan mana } \\
\text { daerah yang diarsir untuk } \\
\text { dihitung luas daerahnya. } \\
\text { - Mencoba menyelesaikan } \\
\text { dengan menggunakan } \\
\text { integral tentu, namun batas } \\
\text { integralnya masih salah, dan } \\
\text { persamaan yang digunakan } \\
\text { untuk menghitung luas } \\
\text { daerahnya masih salah. }\end{array}$ & $\begin{array}{l}\text { langkah-langkah untuk } \\
\text { menyelesaikan } \\
\text { persoalan. } \\
\text { - Tidak bisa membuat } \\
\text { sketsa parabola, } \\
\text { sehingga tidak dapat } \\
\text { menentukan daerah } \\
\text { yang akan dihitung } \\
\text { luas daerahnya. } \\
\text { - Tidak memahami } \\
\text { bagaimana } \\
\text { menggunakan konsep } \\
\text { integral dalam } \\
\text { menghitung luas } \\
\text { daerah. }\end{array}$ \\
\hline $\begin{array}{l}\text { 2. Kemampuan } \\
\text { menggeneralisasi, } \\
\text { yaitu kemampuan } \\
\text { melengkapi data atau } \\
\text { informasi yang } \\
\text { mendukung }\end{array}$ & $\begin{array}{l}\text { - Mencoba merespon dengan } \\
\text { cara melengkapi rata } \\
\text { diberikan secara langsung, } \\
\text { tapi menggunakan konsep } \\
\text { atau aturan integral yang lain, } \\
\text { sehingga tidak dapat } \\
\text { melengkapi data yang } \\
\text { diberikan. }\end{array}$ & $\begin{array}{lr}\text { - Tidak } & \text { memahami } \\
\text { konsep apa yang akan } \\
\text { digunakan r untuk } \\
\text { menyelesaikan } \\
\text { persoalan, rehingg } \\
\text { tidak bisa } & \text { melengkapi } \\
\text { data. }\end{array}$ \\
\hline $\begin{array}{l}\text { 3. Kemampuan } \\
\text { menganalisis } \\
\text { algoritma, } \\
\text { kemampuan } \\
\text { mengevaluasi } \\
\text { memeriksa } \\
\text { algoritma }\end{array}$ & $\begin{array}{l}\text { - Tidak memberikan evaluasi } \\
\text { terhadap permasalahan yang } \\
\text { diberikan } \\
\text { - Memberikan respon dengan } \\
\text { mencoba memberikan } \\
\text { koreksian yang tidak jauh } \\
\text { berbeda dengan peneliti } \\
\text { sajikan, namun masih salah. }\end{array}$ & $\begin{array}{ll}\text { - } & \text { Tidak memahami } \\
\text { konsep integral fungsi } \\
\text { trigonometri, } & \text { sehingga } \\
\text { koreksian yang } & \text { diberikan tidak } \\
\text { menggambarkan } & \\
\text { pemahaman } & \\
\text { seutuhnya. }\end{array}$ \\
\hline
\end{tabular}

\section{Kesimpulan :}

1. Mahasiswa belum mampu untuk mengidentifikasi konsep dan menjastifikasi konsep yang akan digunakan untuk menyelesaikan persoalan yang diberikan.

2. Mahasiswa tidak mengetahui konsep apa yang akan digunakan untuk dapat melengkapi data yang diberikan. Hal ini mengindikasikan bahwa mahasiswa belum memiliki kemampuan untuk menggeneralisasi konsep.

3. Mahasiswa tidak memahami konsep integral trigonometri, sehingga mahasiswa tidak memberikan evaluasi yang benar. Hal ini mengindikasikan bahwa mahasiswa belum memiliki kemampuan untuk mengevaluasi dan memeriksa sebuah persoalan yang ada.

Berdasarkan paparan di atas, maka dapat peneliti simpulkan bahwa mahasiswa belum memiliki kemampuan untuk mengidentifikasi dan menjastifikasi konsep yang diperlukan untuk menyelesaikan masalah. Selain itu, mahasiswa juga belum memiliki kemampuan menganalisis atau mengevaluasi sebuah algoritma. 
Sedangkan apabila dilihat dari level kemampuan matematis, mahasiswa pada level kemampuan tinggi, paling banyak menjawab dengan benar adalah soal untuk indikator 2 yaitu sebanyak 8 orang $(80 \%)$, sedangkan yang paling sedikit menjawab dengan benar adalah soal untuk indikator 1 yaitu sebanyak 4 orang (40\%). Untuk mahasiswa pada level kemampuan sedang, paling banyak menjawab dengan benar adalah soal untuk indikator 2 yaitu sebanyak 75 orang $(85,23 \%)$, sedangkan yang paling sedikit menjawab dengan benar adalah soal untuk indikator 1 yaitu sebanyak 5 orang $(5,68 \%)$. Mahasiswa pada level kemampuan rendah, menjawab dengan benar paling banyak adalah untuk soal indikator 2 yaitu sebanyak 13 orang $(68,42 \%)$, sedangkan untuk soal indikator 1 , semua mahasiswa pada level kemampuan rendah tidak satu orang pun yang menjawab dengan benar.

Berdasarkan hasil analisis lembar jawaban dan hasil wawancara, peneliti mendapatkan beberapa informasi, diantaranya: (1) untuk soal indikator 1, mahasiswa pada level kemampuan tinggi dan sedang sudah bisa menentukan konsep apa yang akan digunakan untuk menyelesaikan persoalan, namun mahasiswa tersebut menemui kesulitan dalam menggambar sketsa kurva dan menentukan batas-batas integralnya. Sedangkan mahasiswa pada level kemampuan rendah, tidak bisa menentukan konsep apa yang akan digunakan untuk menyelesaikan persoalan yang ada; (2) untuk soal indikator 2, mahasiswa pada level kemampuan tinggi, sedang, dan rendah sebagian besar sudah bisa melengkapi data yang diberikan, hal ini disebabkan sebagian besar mahasiswa dari masing-masing level kemampuan sudah memahami konsep integral rasional, sebagian kecil melakukan kesalahan hanya pada menentukan selesaian akhirnya saja; (3) untuk indikator 3, mahasiswa pada level kemampuan tinggi sudah bisa menyatakan bahwa selesaian yang diberikan salah dan bisa menyatakan mana bagian yang salah serta sudah bisa menyatakan jawaban yang benarnya, namun sebagian kecil masih salah dalam menentukan integral trigonometrinya. Sedangkan mahasiswa pada level kemampuan sedang, hanya bisa menyatakan jawaban yang diberikan salah, namun belum bisa menentukan bagian mana yang salah dan menyatakan jawaban yang benarnya. Mahasiswa pada level kemampuan rendah sama sekali belum bisa menentukan apakah jawaban yang diberikan masih salah atau sudah benar.

\section{KESIMPULAN}

Secara keseluruhan dan berdasarkan level kemampuan mahasiswa (tinggi, sedang, dan rendah), mahasiswa mampu menjawab benar dengan persentase paling tinggi adalah pada soal untuk indikator 2 yaitu sebanyak 96 orang $(82,05 \%)$, artinya baik secara keseluruhan maupun berdasarkan level kemampuan (tinggi, sedang, dan rendah), mahasiswa sudah memiliki kemampuan untuk melengkapi data atau melakukan generalisasi. Sedangkan baik secara keseluruhan maupun berdasarkan level kemampuan (tinggi, sedang, rendah), mahasiswa mampu menjawab dengan benar paling sedikit adalah pada soal untuk indikator 1 yaitu sebanyak 9 orang $(7,69 \%)$.

Dapat disimpulkan bahwa, mahasiswa baik secara keseluruhan maupun berdasarkan level kemampuan matematis (tinggi, sedang, rendah), sudah memiliki kemampuan menggeneralisasi, namun belum memiliki kemampuan untuk mengidentifikasi dan menjastifikasi konsep serta belum memiliki kemampuan menganalisis atau mengevaluasi sebuah algoritma. 


\section{DAFTAR PUSTAKA}

Depdiknas (2006).Kurikulum 2006 Standar Isi Mata Pelajaran Matematika.Jakarta: Depdiknas.

Erman Suherman, dkk. (2003). Strategi Pembelajaran Matematika Kontemporer. Bandung: UPI.

Facione, PA (2011). Critical Thinking: What It is and Why it Counts. Think_Critically, Pearson Education.

Fauzan (2002). Applying Realistic Mathematics Education (RME) In Teaching Geometry In Indonesian Primary Schools. Thesis P.hD. Twente.

Firdaus, Kailani.I, Md. Nor Bin Bakar, Bakry. (2015). Developing Critical Thinking Skills of Students in Mathematics Learning. Journal of Education and Learning. Vol. 9(3) pp. 226-236.

Fisher. (2008). Berpikir Kritis Sebuah Pengantar. Jakarta: Erlangga.

Hassoubah, I. Z. (2004). Developing Creatif and Critical Thinking Skill (Cara Berpikir Kreatif dan Kritis). Nuansa: Bandung.

Johnson, E.B. (2007). Contextual Teaching and Learning: Menjadikan Kegiatan BelajarMengajar Mengasyikkan dan Bermakna.(diterjemahkan oleh A. Chaedar Alwasilah), Bandung: Mizan Learning Center.

Karlimah.(2010). Mengembangkan Kemampuan Komunikasi dan Pemecahan Masalah serta Disposisi Matematis Mahasiswa PGSD melalui Pembelajaran Berbasis Masalah. Disertasi pada SPs UPI Bandung: Tidak diterbitkan.

Lipman, M. (2003). Thinking in Education. New York: Cambridge University Press.

Lunenburg, F.C (2011). Critical Thinking and Constructivism Techniques for Improving Student Achievement. National Forum Of Teacher Education Journal VOLUME 21, NUMBER 3, 2011

Marzano, R. J. (1989). Dimention of Thinking : A Framework for Curriculum and Instruction. AlexanderiaUS : Association for Supervision and Curriculum Development.

Sabandar, J. (2007). Berpikir Reflektif. Makalah disampaikan pada Seminar Nasional Sehari: Permasalahan Matematika dan Pendidikan Matematika Terkini tanggal 8 Desember 2007, UPI Bandung: Tidak diterbitkan.

Santrock, J.W. (1997). Adolescence. London: Mc-Graw-Hill, Inc.

Somakim.(2010). Peningkatan Kemampuan Berpikir Kritis dan Self-Efficacy Matematik Siswa Sekolah Menengah Pertama dengan Penggunaan Pendekatan Matematika Realistik. Disertasi pada Sekolah Pascasarjana Universitas Pendidikan Indonesia. Disertasi tidak diterbitkan.

Sugiyono.(2011). Metode Penelitian Pendidikan (Pendekatan Kuantitatif, Kualitatif, dan $R \& D$. Bandung: Alfabeta. 